\title{
Hyperhidrosis and its Prevalence in a Population: A Cross Sectional Survey
}

\author{
Mubashar Mashqoor Mir ${ }^{1 *}$ and Mohammad Sarwar Mir ${ }^{2}$ \\ ${ }^{1}$ Department of Dermatology, Government Medical College, India \\ ${ }^{2}$ Senior Resident, Department of Hospital Administration, India
}

Submission: May 21, 2018; Published: September 24, 2018

"Corresponding author: Mubashar Mashqoor Mir, Post Graduate Resident, Department of Dermatology, Government Medical College, Jammu, India, Email: mohammedsarwarmir@gmail.com

\section{Abstract}

\section{Background}

Hyperhidrosis is a quite common condition. There is a wide variation in the reported prevalence of hyperhidrosis in the available literature.

Objectives

This study aims to examine the prevalence of hyperhidrosis [1].

\section{Methods}

A cross sectional survey of a population was carried out. The subjects were classified to have hyperhidrosis using the criteria of International Hyperhidrosis Society. The prevalence of $\mathrm{HH}$ was calculated for the entire study population.

Results

The prevalence of hyperhidrosis was 3.2\% (320 cases) in the study population of 10000 .

\section{Conclusion}

Hyperhidrosis affects a much larger population than previously reported.

Keywords: Prevalence, Hyperhidrosis, Population; Cross-sectional study

\section{Introduction}

Hyperhidrosis ( $\mathrm{HH}$ ) is a condition characterized by excessive sweating without the usual triggers such as mental, physiological or thermal stimuli. There are two broad categories of hyperhidrosis, secondary and primary. Secondary hyperhidrosis occurs with an underlying medical condition, such as chronic infections and other catabolic conditions [1]. In contrast, primary hyperhidrosis (primary $\mathrm{HH}$ ) occurs in a symmetrical fashion with an age of onset less than 30 years and without underlying medical conditions. While the significant negative impact of primary $\mathrm{HH}$ is well known, especially in developed countries [2] there have been large variations in the prevalence of primary $\mathrm{HH}$ in various reports, ranging from $2.8 \%$ in the United States [3], to $16.3 \%$ in Germany [4] and $12.8 \%$ in Japan [5], the reasons for the discrepancies are not known. However, the demographical and geographical aspects of various studies differ from one study to the next. Further, the criteria used for the diagnosis and classification of $\mathrm{HH}$ also varied from study to study.

\section{Methods}

It was a cross sectional survey carried out in a rural community in Srinagar in April 2014. The subjects were classified to have hyperhidrosis using the criteria of International Hyperhidrosis Society. The prevalence of $\mathrm{HH}$ was calculated for the entire study population. The questionnaire contained the following components: age, sex, reasons for presenting for dermatological assessment, symptoms related to day-time.

\section{Statistical Analysis}

The data analysis was performed with Microsoft Excel and SPSS 20. The prevalence of $\mathrm{HH}$ was measured for the whole population.

\section{Discussion}

Hyperhidrosis $(\mathrm{HH})$ is a condition characterized by excessive sweating without the usual triggers such as mental, physiological or thermal stimuli. There are two broad categories of hyperhidrosis, 
secondary and primary. Much of the current knowledge is directed on treatment while only a few studies are focused on determining the prevalence. In our study the prevalence of hyperhidrosis was $3.2 \%$. The prevalence of primary hyperhidrosis has been the subject of examination by several groups focusing on populations that differ in ethnic compositions, geographical locations, age, and gender. However, the findings vary from one study to the other: $2.8 \%$ in the United States [3], 4.4\% PPH in Fuzhou, China [6], $16.3 \%$ in Germany [4] and $12.8 \%$ in Japan [5]. Possible reasons for the wide variation may include differences in study methods, precise definitions used, ethnic composition of the study subjects, age, gender and the environment. Females were the dominant sex affected in our study and also axillary hyperhidrosis was the commonest site affected. Also, majority of the patients had positive history of hyperhidrosis. Further studies are needed to understand the distribution, and effect of hyperhidrosis in this part of world and to identify the aggravating factors (Tables 1-4).

Table 1: Showing Prevalence of Hyperhidosis.

\begin{tabular}{|c|c|c|}
\hline Status & Frequency & Percentage \\
\hline Positive & 320 & $3.20 \%$ \\
\hline Negative & 9680 & $96.80 \%$ \\
\hline Total & 10000 & $100.00 \%$ \\
\hline
\end{tabular}

Table 2: Gender wise distribution of cases.

\begin{tabular}{|c|c|c|}
\hline Gender & Frequency & Percentage \\
\hline Male & 140 & $43.75 \%$ \\
\hline Female & 180 & $56.25 \%$ \\
\hline Total & 320 & $100.00 \%$ \\
\hline
\end{tabular}

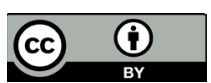

This work is licensed under Creative

Commons Attribution 4.0 License
Table 3: Site of hyperhidrosis.

\begin{tabular}{|c|c|c|}
\hline Site & Frequency & Percentage \\
\hline Axillary & 160 & $50.00 \%$ \\
\hline Palmar & 60 & $18.75 \%$ \\
\hline Plantar & 30 & $9.38 \%$ \\
\hline Face or scalp & 26 & $8.13 \%$ \\
\hline Groin & 24 & $7.50 \%$ \\
\hline Others & 20 & $6.25 \%$ \\
\hline Total & 320 & $100.00 \%$ \\
\hline
\end{tabular}

Table 4: Family history.

\begin{tabular}{|c|c|c|}
\hline Family history & Frequency & Percentage \\
\hline Positive & 175 & $54.68 \%$ \\
\hline Negative & 145 & $45.31 \%$ \\
\hline Total & 320 & $100.00 \%$ \\
\hline
\end{tabular}

\section{References}

1. Liu Y, Bahar R, Kalia S, Huang RY, Phillips A, et al. (2016) Hyperhidrosis Prevalence and Demographical Characteristics in Dermatology Outpatients in Shanghai and Vancouver. PLoS ONE 11(4): e0153719.

2. Gross KM, Schote AB, Schneider KK, Schulz A, Meyer J (2014) Elevated social stress levels and depressive symptoms in primary hyperhidrosis. PLoS One 9(3): e92412.

3. Strutton DR, Kowalski JW, Glaser DA, Stang PE (2004) US prevalence of hyperhidrosis and impact on individuals with axillary hyperhidrosis: results from a national survey. J Am Acad Dermatol 51(2): 241-248.

4. Augustin M, Radtke MA, Herberger $\mathrm{K}$, Kornek T, Heigel $\mathrm{H}$, et al. (2013) Prevalence and disease burden of hyperhidrosis in the adult population. Dermatology 227(1): 10-13.

5. Fujimoto T, Kawahara K, Yokozeki H (2013) Epidemiological study and considerations of primary focal hyperhidrosis in Japan: from questionnaire analysis. J Dermatol 40(11): 886-890.

6. Li X, Chen R, Tu YR, Lin M, Lai FC, et al. (2007) Epidemiological survey of primary palmar hyperhidrosis in adolescents. Chin Med J (Engl) 120(24): 2215-2217.

Your next submission with Juniper Publishers
will reach you the below assets
- Quality Editorial service
- Swift Peer Review
- Reprints availability
- E-prints Service
- Manuscript Podcast for convenient understanding
- Global attainment for your research
- Manuscript accessibility in different formats
( Pdf, E-pub, Full Text, Audio)
- Unceasing customer service
Track the below URL for one-step submission
https://juniperpublishers.com/online-submission.php

